\title{
Urban Identity from the Perspective of Urban Atmosphere Case Study: Klungkung, Bali, Indonesia
}

\author{
I Made Agus Mahendra ${ }^{1)}$,Syamsul Alam Paturusi ${ }^{2)}$,Ngakan Ketut Acwin Dwijendra ${ }^{3)}$, \\ I Dewa Gede Agung Diasana Putra ${ }^{4}$ \\ 1a) Student of Doctoral Program Engineering Science, Udayana University, ${ }^{1 b)}$ Lecture \\ Of Engineering Faculty, Mahendradatta University, 2,3,4) Lecture of Doctoral Program Engineering Science, \\ Udayana University \\ ${ }^{1)}$ made.agusmahendra@gmail.com, ${ }^{2)}$ syamsul@unud.ac.id, ${ }^{3)}$ acwin@unud.ac.id, ${ }^{4)}$ diasanaputra@unud.ac.id,
}

\begin{abstract}
Urban areas are areas that give different atmosphere and taste in different places. There are aspects that can affect the atmosphere of urban areas. Where in each urban area has different characteristics. Klungkung city area which basically is strongly influenced by the strong cultural character of the past. Urban atmosphere has a very important role in the identity of urban areas. cities on the island of Bali have unique and unique characteristics that make the city atmosphere different. Moreover, Bali in national and international scope already has an attraction that cannot be separated from the atmosphere of the island of Bali. The atmosphere of the city space gives a different atmosphere both in the identity and character of the urban area of Klungkung, Bali. In the urban environment there is a spatial atmosphere as an indicator and reference for the development of the identity of the Klungkung urban area, Bali. This research is motivated by the lack of understanding and understanding of the community, institutions and local governments about the atmosphere of urban space. The atmosphere of urban space provides a very important understanding and analysis of the taste and atmosphere of urban areas. The approach to the atmosphere of the city can be seen from nine aspects that must be considered in creating atmosphere in buildings and cities. The atmosphere in this study has the meaning of the sense of taste, the atmosphere in which a person is in space, creativity, taste and intention that form a shelter in a particular area. The atmosphere in this study emphasizes the atmosphere, the meaning of space and taste which includes local Balinese culture, especially in the city of Klungkung. This research uses qualitative methods by emphasizing descriptive studies, and literature studies. This study aims to determine the urban atmosphere of the Klungkung region and the relationship between the urban atmosphere and the identity of the Klungkung Bali urban area. From the results of the analysis in the conceptual order, the benefits and results obtained provide an overview of the atmosphere of the urban space as one of the identity of the Klungkung Bali urban area.
\end{abstract}

Index Terms - Urban atmosphere, urban identity, urban space, urban areas

\section{INTRODUCTION}

\section{A. Bakground}

Klungkung city area is an area that has an identity in space and culture within the scope of the urban atmosphere that holds it. The city as a reflection of society cannot be separated from the existence of historic buildings that become the identity of a city. [3], [10Urban identity basically cannot be built but formed by itself. City identity is formed from the meaning and meaning of "image" about something that exists or already exists / is attached to the city or the introduction of physical objects (buildings and other physical elements) as well as non-physical (social) objects. activities) that are formed from time to time. Historical aspects and the introduction of "pictures" taken by city dwellers are important for understanding city identity or regional images (Wikantiyoso 2006). The identity of urban areas is very important in the concept of urban area development. There are several things that become the main points in urban identity, namely the concept, character and meaning of a city

will never be separated from its identity, therefore it is very important as the paradigm of the city itself. The identity of a city is a unique condition and characteristic that distinguishes it from other cities

City identity is a powerful concept for creating images in someone's mind that have never been understood before. City identity can be physical or psychological. Physical identity is the identity of the city that can be seen tangible (tangible) in the physical form of the infrastructure of the city itself, both in the form of buildings, fields, squares, parks, terminals, markets, hospitals, residential areas, heritage, monuments and various other forms of physical facilities that 
can represent the existence of the city itself. While the psychic identity of the city can mean the psychological identity of city life (intangible) that affects the face of the city, both in the form of the rhythm of people's lives, the spirit of the people or culture that lives in harmony. a city which is a symbol and pattern of the functions of city life, thus providing a different identity for the city (Tjahyoko 2008). In connection with the meaning of city identity, historical and socio-cultural values will be seen from the process of developing the function of city life. Or in other words, the process of developing the life functions of a city can be seen as a collection of data that can be used as a starting point for each step of the meaning of the city's identity

The space that becomes the container of activity is strived to meet the needs that may be needed by humans, which means providing a space that gives satisfaction to the wearer. Regulations are directly related to human activities so that by identifying systems of activities that occur in a space will also be identified system settings related to the presence of elements in space (Rapoport, 1991).

Balinese Spatial Patterns In Balinese cultural values there are concepts of the Great Bhuana (macro cosmos) and Bhuana Alit (micro cosmos), which always maintain harmony between the two. From these two concepts, it was revealed to be an approach in spatial planning. The basis of the spatial value system emphasizes meaning, in the context of spatial culture, which includes basic taxonomic values, which include religious values, aesthetic values, values of solidarity (mutual cooperation)) and balance values. While the instrumental value, which includes a set of value systems that support adaptive dynamics (flexible-flexible-dynamic) and flexible in accordance with the village of adigium, kala, patra.

Strong history, thick cultural heritage provides a different atmosphere in the urban area of Klungkung. From the scope of the atmosphere of urban space gives different meanings and perceptions of the people who have come and done their activities.

\section{B. . Research Question}

From the background description mentioned above, it can be formulated several research questions faced by Klungkung urban areas related to identity from the perspective of the urban atmosphere are as follows:

1. What is a general description of the urban space atmosphere in the Klungkung area?

2. How is the urban atmosphere related to the identity of the Klungkung city area?

\section{Research Objectives}

This research topic choice focuses on Urban Atmosphere in the urban space approach that influences the identity of urban areas.This study looks for regional spatial approaches in the framework of Urban Atmosphere which has a purpose
1 Knowing how the atmosphere of the City can affect the identity of the City area

2 Knowing the contribution of Urban Atmosphere given in the sense of urban space

\section{LITERATURE REVIEW}

A. The identity of urban areas is very important in the concept of urban area development. There are several things that become the main points in urban identity, namely the concept, character and meaning of a city will never be separated from its identity, therefore it is very important as the paradigm of the city itself. [8],[13],

Space is a container or physical arrangement that can influence the offender or user. The definition of space itself is the smallest built environment system where most of human time is spent in it. Space cannot be separated from humans either psychologically, emotionally or in dimensions. Humans are in space, moving, living and thinking, also making space to create their world. [11],[3],

According to Endy Marlina (1998), derived from spatial words which in the dictionary means space. Room. Derived from spatial words that are closely related to understanding the environment in which to move and carry out activities. Spatial discussion of Akian is closely related to the understanding of space as space for movement. Spatial planning is not only related to the idea of physical space but also related to activities and people as actors of this activity. According to RI Law No. 24 of 1992 (in Cemporaningsih, 2007), spatial is spatial, spatial itself is derived from the word space, which is a container that includes land space, sea space, air space as an area of unity, where humans and other creatures live and carry out activities and maintain its survival. [6],[7],

B. The atmosphere generally has an understanding of the earth's blanket layers in the air. The atmospheric layer that is on the earth's blanket serves as a protector as well as a barrier to various foreign objects that come from outer space. In addition, the atmosphere usually also affects the weather and climate that occur on earth. In the Big Indonesian Dictionary, the atmosphere has 3 meanings: 1 . the layer of air that envelops the earth to an altitude of $300 \mathrm{~km}$ (consisting mainly of a mixture of various gases, namely nitrogen, oxygen, argon, and other small amounts). gas) 2. a unit of pressure equal to the air pressure at sea level $(1,033 \mathrm{~kg}$ per $\mathrm{cm} 2) .3$ imaginative mood in a play made by the author.

Peter Zumthor In a book entitled "Atmosphere Architectural Environment and Surrounding Objects says that the atmosphere is an architectural state when buildings can 'move' users. The term atmosphere was born from Peter Zumthor's anxiety about the quality of architectural works. The quality of architectural works is not about architectural rules but about how presenting a natural element in design, in the design process, it must have an intrinsic context that first considers and reviews 'things that are not seen' (sensory experience) to be able to create 'things that are visible' (buildings) quality and architecture are not limited to something seen, but also to feel and presence, i.e. how the presence of an architectural building affects anyone who 
sees, enjoys, or is involved with a building, its form is simple but has a strong substance.The design process always uses an invisible approach, namely ' experience sensors' unt uk any architectural design object. [15],[16],

The approach is elaborated into nine aspects that must be considered in creating the atmosphere in a building, namely;

(1) The body of architecture; (2) Material compatibility; (3) The sound of a space; (4) The temperature of a space; (5) Between composure and seduction; (6) Surrounding objects;

(7) Tension between interior and exterior; (8) Levels of intimacy; (9) The light on things (Zumthor, 2006). Peter Zumthor's Atmospheric Theory put more emphasis on "Atmosphere (atmosphere)" in applying all aspects of design in buildings and more emphasis on material as one of the main things in the creation of Peter Zumthor's atmosphere. [15],[16],

In terms of the economy that is more specific to commercial stores, according to Revars quoted by Alma (2005: 60) Atmosphere is the atmosphere of the store which includes interior, exterior, layout, internal store traffic, air comfort, service, music, uniforms, sales force, displaying goods that attract consumers and the desire to buy. On the other hand according to Ma'ruf (2005: 206) the atmosphere is the atmosphere in the store that creates certain feelings for customers arising from the use of elements of interior design, lighting management, sound management, systems and air conditioning services. .

The atmosphere is the atmosphere within the scope of the region // region that creates a certain feeling in humans / society arising from the elements of physical regulation and regulation of social and cultural activities of the people who are in the area. [15],[16]. The atmosphere in this study has the meaning of the sense of taste, the atmosphere in which a person is in space, creativity, taste and intention that form a shelter in a particular area. The atmosphere in this study emphasizes the atmosphere, the meaning of space and taste which includes local Balinese culture, especially in the city of Klungkung.

C. The image of the city can be defined as follows, "City image is a mental picture of the city in accordance with the views of the average population". (Zahn Markus, 1999). The image of the city is formed from several elements according to Kevin Lynch, namely: Landmarks, edges, paths, vertices, and districts. aspects of the city image include Legibility (Identity), Identity and Composition, Imageability, Visual and Symbol Conection. From the image of the city image obtained and analyzed, it is then derived into the elements that form the face of the city,

Charles Correa's understanding of identity is stated (in Budihardjo, 1997) that: "Identity is a process, not an object that is found that can be made up". Correa's opinion in his writing "Quest for Identity" is more focused on forms of identity associated with the field of architectural design. In line with Correin's opinion, Budihardjo (1997) also explained that an expert said "identity is a moving target", identity is a target that always changes with time and society, as a process that cannot be made. Identity in traditional societies manifests more as a reflection of the creative abilities of people in manifesting their cultural behavior, and

P-ISSN: 2579-597X, E-ISSN: 2579-5988 not just the distinctiveness of products or cultural artifacts that are identical all the time.. [16],[18]..

\section{RESEARCH METHODS}

This research method uses a descriptive qualitative approach with urban area space that uses indicators of the atmosphere of the urban atmosphere. Where in this study explained, identification of the urban space atmosphere using qualitative methods, and literature studies. Data collection techniques are done by direct observation in the field, interviews, and literature studies relating to the urban atmosphere which is one of the identity of the city of Klungkung. This study aims to determine the urban atmosphere of the Klungkung region and the relationship between the urban atmosphere and the identity of the Klungkung city area. From the results of the analysis in the conceptual order, the benefits and results obtained provide an overview of the atmosphere of the urban space as one of the identities of the Klungkung city area..

\section{RESULT AND DISCUSSION}

This research takes place in the Klungkung Regency and focuses on the Klungkung urban area. With an emphasis on an overview of the urban atmosphere around the Klungkung urban area.

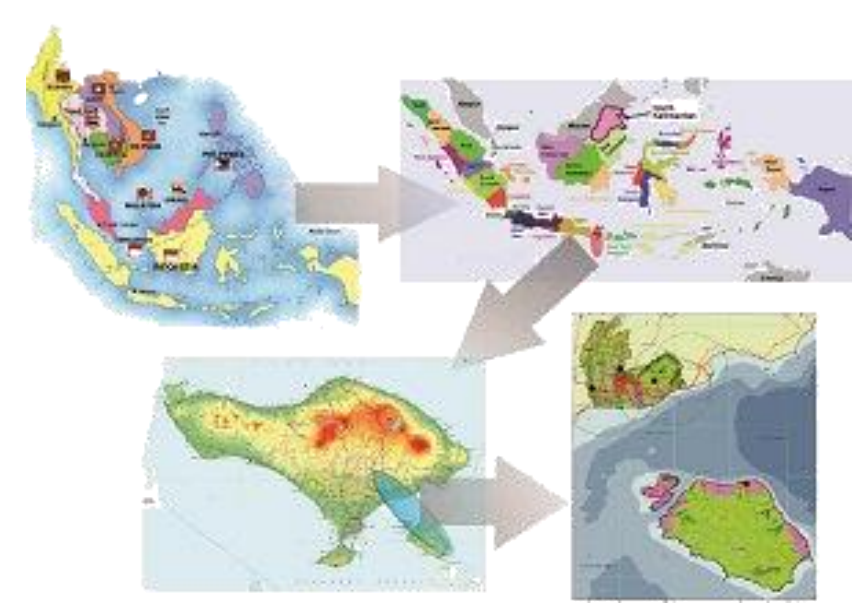

Figure 1: The position of the City of Klungkung towards Southeast Asia

Source: analysis results

The research location is Klungkung Regency, which is the smallest of 9 (Nine) Regencies and Cities in Bali Province with an area of $315 \mathrm{~km} 2$. The boundaries of Klungkung Regency are north bordered by Bangli Regency, east bordering Karangasem Regency in the southern Indian Ocean and west bordering Gianyar Regency. 

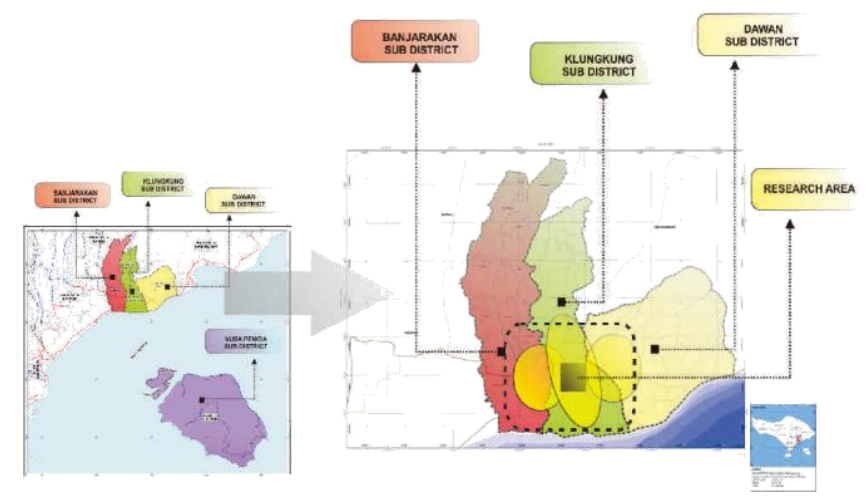

Figure 2: Focus of research location in Klungkung

Source: analysis results

Discussion about urban environment, adopting Peter Zumthor's theory with the application of nine aspects of design. In every design process, Peter Zumthor always emphasizes or uses an invisible approach, namely 'sensory experience' for each architectural design object. The approach materialized into a design atmosphere which was then elaborated into nine aspects of design. In terms of urban atmosphere, nine aspects of this design will be used to discuss the atmosphere of the Klungkung city area.

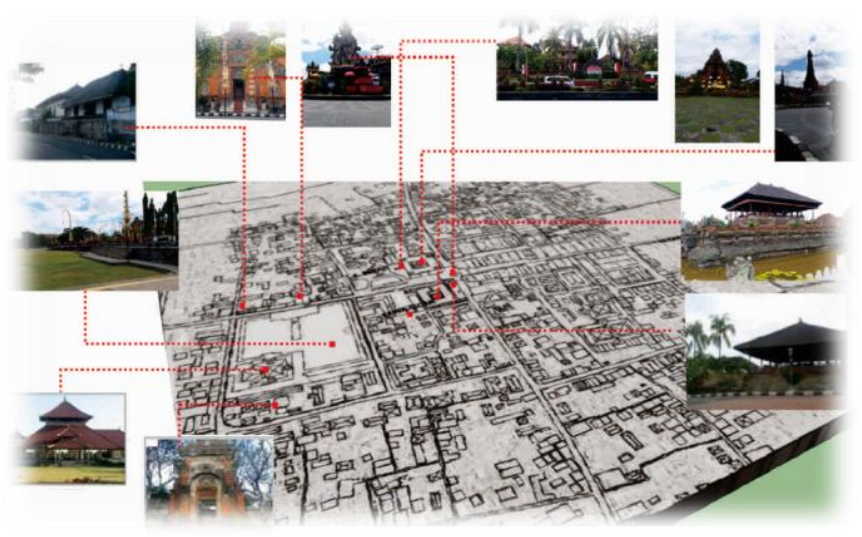

Figure 3: Core buildings surrounding the Klungkung urban area Source: analysis results

\section{The Body of Architecture}

Just like humans, architecture also has a body. Architectural body anatomy includes 'skin and organs' (visible parts) and 'anatomical systems of cells in the body' (invisible). In the atmosphere of urban space can be implemented into a collection of buildings that form the structure of space with the concept of division Angga tri in the concept of Balinese architecture, namely the head of the body and legs that became an urban space

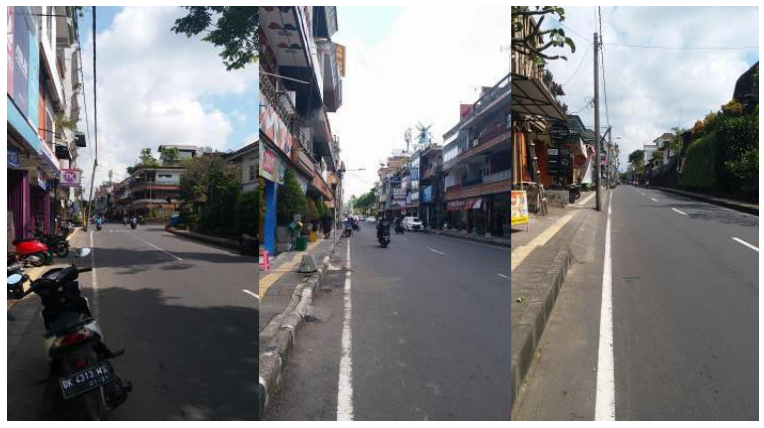

Figure 4 : The Body of Architecture in the Klungkung urban area Source: analysis results

\section{Material Compatibility}

In feeling the atmosphere of urban areas, must have an extraordinary sensitivity to the material used. Each material has its own uniqueness that can reflect the uniqueness of a place or region. Material has 'sustainable' nature, is flexible there are no restrictions in managing and using it. If two different materials are collaborated, at some point they are the opposite, but at one point they support each other by producing a unique identity of a region

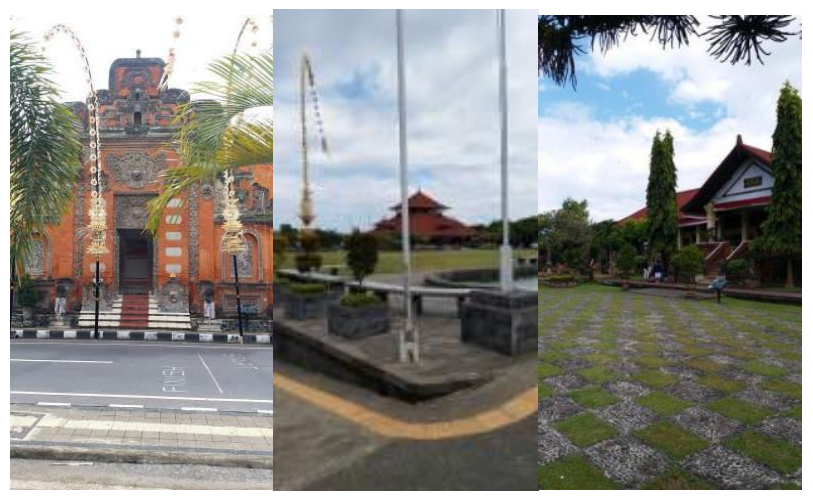

Figure 5 : Material Compatibility in the Klungkung urban area Source: analysis results

\section{The Sound of a Space}

Klungkung Urban Area has memiliki tone 'and' rhythm 'in each of its buildings which is reflected in the regional spaces with various function functions. Regional space becomes a sound forming instrument or instrument. This relates to the shape and surface space (use of material)

\section{The Temperature of Space}

Temperature is divided into two, physical temperature and psychological temperature. Physical temperature is influenced by materials used by buildings. As for psychological temperatures, this is more about how the state and atmosphere of a space affects the 'mood \& feelings' of people in urban areas of Klungkung. 


\section{Surrounding Objects}

This aspect is about anything that is around a building or space - human beings, any object - that can arouse the atmosphere, imagination, beauty, or attraction. Klungkung urban Kawqsan has art and culture that contributes to the atmosphere and sense of beauty in each building which has a high historical value
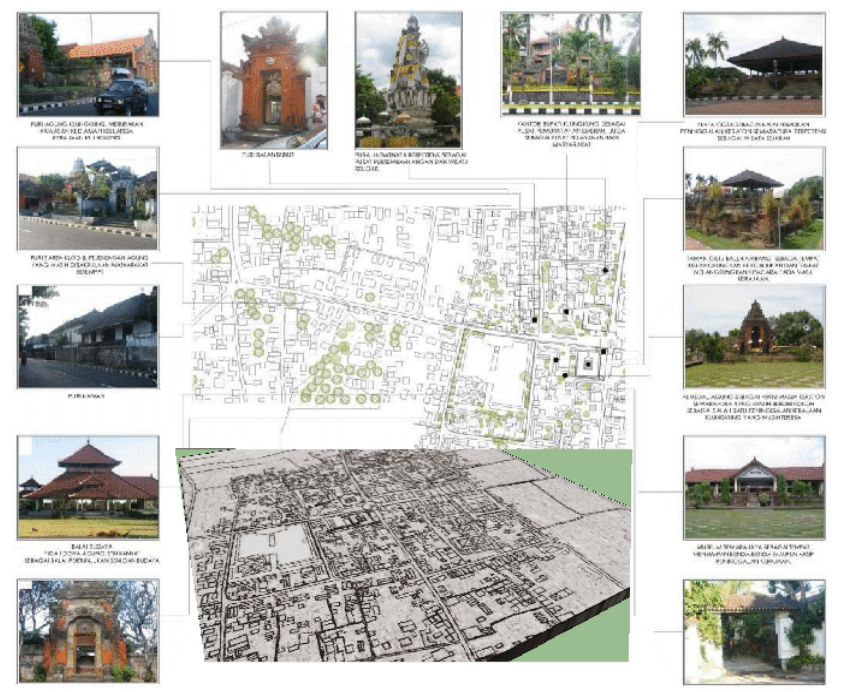

.

Figure 6: Surrounding Objects in the Klungkung urban area Source: analysis results

\section{Between Composure and Seduction}

The presence of forms, spaces, or anything from a building has 'movements', 'paths', 'sequences', which also naturally 'guide', 'stimulate', and provide 'relaxation' so that people in urban areas of Klungkung interact with buildings can feel calm and free - it can be said that space \& buildings direct behavior.

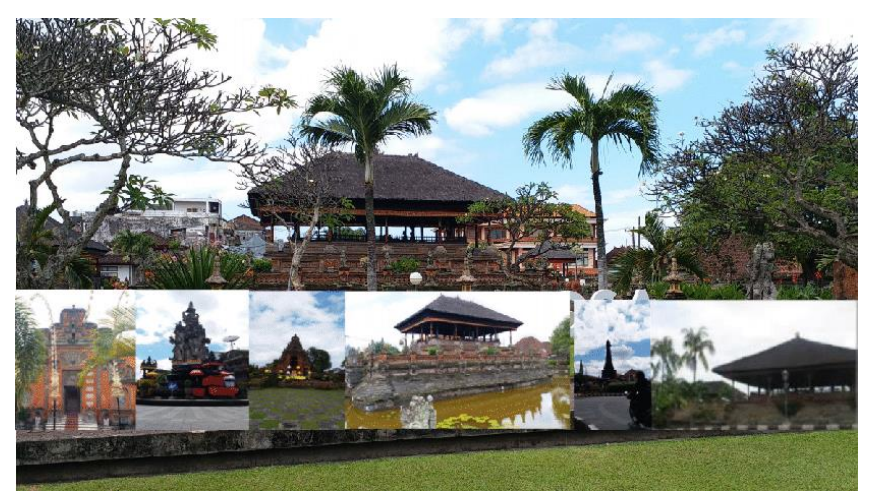

Figure 7 : Between Composure and Seduction in the Klungkung urban area Source: analysis results

\section{Tension Between Interior \& Exterior}

Space inside and outside space, although in terms of form,

P-ISSN: 2579-597X, E-ISSN: 2579-5988 nature, and function are different, but binding together. The treatment of both determines the character of the building. For example the openings made affect the building facade, and indirectly present the character of the building in the urban area of Klungkung.

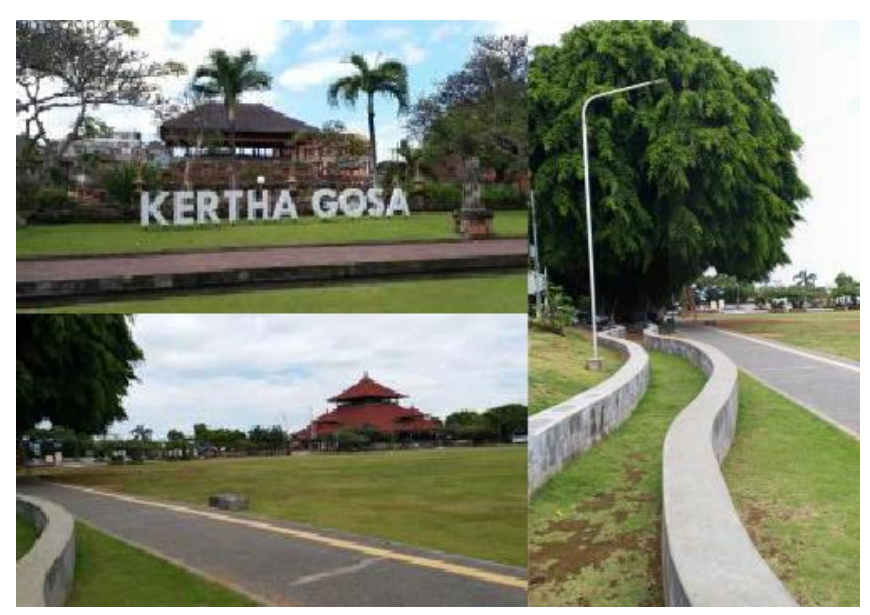

Figure 8 : Tension Between Interior \& Exterior in the Klungkung urban area Source: analysis results

\section{Levels of Intimacy}

This relates to the scale, size, and dimensions of shapes, spaces, and openings in buildings. these things become factors in the presence of the building as if it has a 'story line' someone who interacts with the existing building, the scope of urban space Klungkung which is one of the identity markers of the regional character.

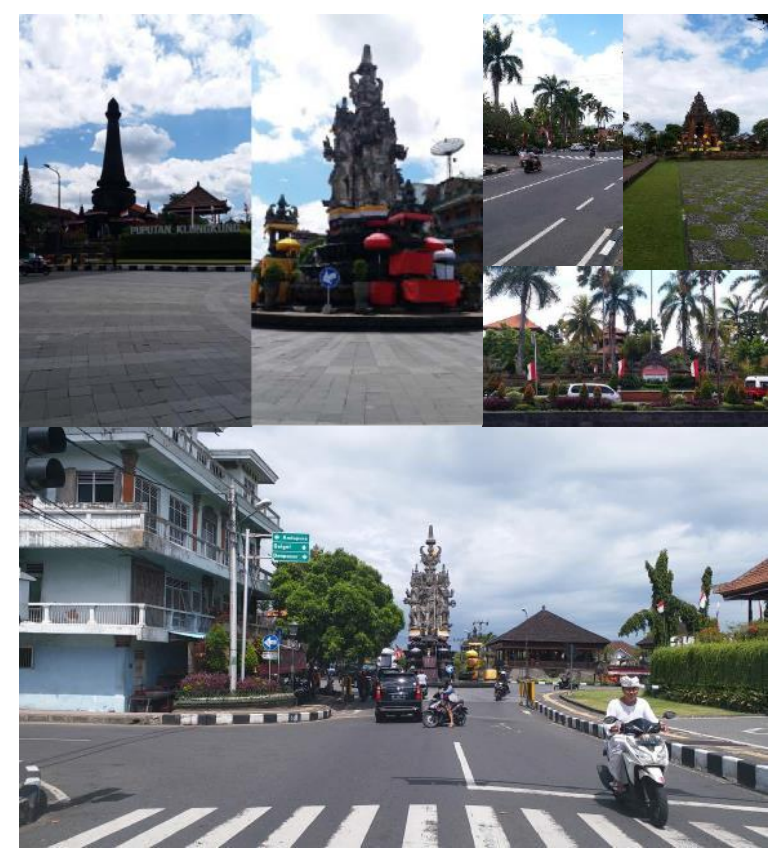

Figure 9 : Levels of Intimacy in the Klungkung urban area Source: analysis results 2019 


\section{The Light on Things}

The building is considered a 'pure mass of shadow' which is then perforated with (given) light. The intended light is natural light and artificial light. In the use of materials that will later reflect natural light, or in making openings and using artificial light, the first thing to consider is how the light falls, and the position and shape of the shadows will have their own effects and also affect the spiritual quality of buildings in the Klungkung urban area.

Table 1: The relationship between analysis of city image theory and Atmospheric theory in the identity of Urban

Areas

\begin{tabular}{|l|l|l|}
\hline $\begin{array}{c}\text { City Image } \\
\text { Theory } \\
\text { "Kevin }\end{array}$ & $\begin{array}{l}\text { Atmosphere } \\
\text { Theory "Peter } \\
\text { Zumthor" }\end{array}$ & \multicolumn{1}{|c|}{ Urban Identity } \\
\hline Legibility & $\begin{array}{l}\text { The Body of } \\
\text { Architecture }\end{array}$ & $\begin{array}{l}\text { Give a symbol or } \\
\text { sense of direction to } \\
\text { the center of urban } \\
\text { areas }\end{array}$ \\
\hline $\begin{array}{l}\text { Identity and } \\
\text { structure }\end{array}$ & $\begin{array}{l}\text { Functionally, it gives } \\
\text { a characteristic } \\
\text { identity of what } \\
\text { Material } \\
\text { Compatibility } \\
\text { functions are felt in } \\
\text { urban areas }\end{array}$ \\
\hline $\begin{array}{l}\text { Imageability } \\
\text { The Sound of a } \\
\text { Space, } \\
\text { Surrounding } \\
\text { Objects, }\end{array}$ & $\begin{array}{l}\text { A sense that shows } \\
\text { that the harmony and } \\
\text { harmony of urban } \\
\text { communities in } \\
\text { appreciating the } \\
\text { region }\end{array}$ \\
\hline $\begin{array}{l}\text { Visual and } \\
\text { symbol } \\
\text { connections }\end{array}$ & $\begin{array}{l}\text { Tension Between } \\
\text { Interior \& } \\
\text { Exterior, The } \\
\text { Light on Things } \\
\text { Surrounding } \\
\text { Objects, } \\
\text { Levels of } \\
\text { Intimacy }\end{array}$ & $\begin{array}{l}\text { Provide a sense, } \\
\text { creativity and } \\
\text { initiative in the } \\
\text { integration of urban } \\
\text { areas }\end{array}$ \\
\hline
\end{tabular}

Source: Author Analysis 2019

\section{CONCLUSION}

In the Klungkung Urban area, the atmosphere of the urban area has a very significant role in the identity of the urban area. This very important role will continue to be developed to get the right formulation in determining the identity of an urban area. from 9 aspects of Peter Zumthor's theory of Atmosphere, there are The Body of Architecture The Temperature of Space, Material Compatibility The Sound of a Space, Surrounding Objects, Tension Between Interior \& Exterior, The Light on Things Surrounding Objects Levels of Intimacy that can describe the atmosphere in general Klungkung urban area.

The identity of the city is formed from the meaning and meaning of "image" about something that exists or already exists in the urban atmosphere or the introduction of physical objects that form from time to time. Historical aspects and the introduction of "atmosphere" taken by city dwellers are important for understanding city identity

\section{ACKNOWLEDGMENTS}

Acknowledgments I offer to those who have supported and provided input for this paper, including lecturers in the Doctor of Engineering program, engineering faculty at Udayana University, Mahendradatta University as my teaching place, Klungkung Regency Government, Spatial Planning Office and Culture Office, Youth and Sports and all residents and respondents from Klungkung Regency

\section{REFERENCES}

[1] Budihardjo, Eko. 1986. Architectural Consevation in Bali (Gajah mada University Press: Yogyakarta ).

[2] Trancik, Roger. 1986. Finding Lost Space; Theories of Urban Design (Van Nostrand Reinhold Company: New York).

[3] Budihardjo, Eko. 1986. Architectural Conservation in Bali. Yogyakarta: Penerbit Gajah Mada University Press.B. Smith, "An approach to graphs of linear forms (Unpublished work style)," unpublished.

[4] Budihardjo, Eko. 1998. Percikan Masalah Arsitektur Perumahan Perkotaan Yogyakarta: Gadjah Mada University Press.

[5] Dwijendra. Ngakan Ketut Acwin. (2016). Revitalisasi Arsitektur Kawasan Pusaka di Bali . Bali: Penerbit STD Bali Press..

[6] Julia Winfield-Pfefferkorn, The Branding of Cities : Exploring CityBranding and Importance of Brandi Image, Master Thesis, The Graduate School of Syracuse University, 2005.

[7] Kostof, S., 1991, The City Shaped: Urban Patterns and Meanings Through History, Thames and Hudson, London.

[8] Paturusi, Syamsul Alam. 1988. Pengaruh Pariwisata terhadap Pola Tata Ruang Perumahan Tradisional Bali. Bandung: Thesis S2 Program Perencanaan Wilayah dan Kota ITB.

[9] Rappoport, Amos. 1977, Human Aspects of Urban For Oxford : Pergamon Press.

[10] Sinamo H. J. 2007. Manusia, Kota, dan Etos Pembangunan. Seminar Internasional The Knowledge City: Spirit, Character, and Manifestation. 13-14 November 2007. Danau Toba

[11] Shirvani, Hamid. 1985. The Urban Design Process. New York: Van Nostrand Reinhold Company.

[12] Spreiregen, P. D. 1965. Urban Design: The Architecture of Towns and Cities. New York: McGraw Hill Book Company.

[13] Trancik, Roger. 1986. Finding Lost Space; Theories of Urban Design. New York: Van Nostrand Reinhold Company.

[14] Zahnd, Markus. 1999. Perancangan Kota Secara Terpadu; Teori Perancangan Kota dan Penerapannya. Yogyakarta:Penerbit Kanisius.

[15] Zumthor, Peter. 1999. Thinking Architecture. Birkhäuser, Germany.

[16] Zumthor, Peter. 2006. Atmospheres. Birkhäuser Verlag AG, Berlin.

[17] Gelebet, I.N.M., I W., Negara Yasa, I M., Suwirya, I M.,Surata, I N 1985. ArsitekturTradisional Daerah Bali, Departemen Pendidikan dan Kebudayaan: Proyek Inventarisasi dan Dokumentasi Kebudayaan Daerah.

[18] Lynch, K. (1960). The Image of The City. England: The M.I.T. Press. 